\title{
Implementation of Content and Language Integrated Learning and Its Effects on Student Motivation
}

Implementación del aprendizaje integrado de contenidos y lenguas

extranjeras y sus efectos sobre la motivación de los estudiantes

Implementação de uma aprendizagem integrada de conteúdos e línguas estrangeiras e seus efeitos na motivação dos alunos

Enisa MEDE

orcid.org/oooo-0002-6555-5248.

Bahçeşehir Üniversitesi, Turkey.

enisa.mede@es.bau.edu.tr

Senanur ÇINAR

orcid.org/0000-0003-4705-2310

İstanbul Gelişim Üniversitesi, Turkey.

scinar@gelisim.edu.tr

Received: 19-06-2018

Accepted by peers: 02-11-2018
Sent for peer review: 02-11-2018

Approved: 06-11-2018

To reference this article (APA) / Para citar este artículo (APA) / Para citar este artigo (APA) Mede, E. \& Çinar, S. (2018). Implementation of Content and Language Integrated Learning and its effects on student motivation. LACLIL, 11(2), 215-235. DOI: 10.5294/laclil.2018.11.2.3 
ABSTRACT. The aim of the present study is to examine the effects of integrating Content and Language Integrated Learning (CLIL) on the motivation of students learning English in a preparatory school at a private university in Istanbul, Turkey. The study also attempts to find out how the students and their instructor perceive teaching and learning English through this particular approach. The participants consisted of 19 intermediate level students and their instructor. To meet these objectives, the quantitative data were collected through pre- and post-motivation questionnaires whereas the qualitative data came from reflective journals kept by the two CLIL had a positive influence on the students' motivation while learning English. In addition, the reflective journals suggested that both students and their instructor perceived CLIL as an engaging and functional instructional tool while teaching and learning English. CLIL also helped students to become more responsible for their own learning process. Finally, the two groups of participants shared the difficulties they experienced with this approach, such as timing, workload and speaking. Based on these findings, the study offers recommendations and implications about using CLIL in English classrooms.

Keywords (Source: Unesco Thesaurus): Content and language integrated learning; CLIL; motivation; higher education; English; language teaching; language instruction; language learning.

RESUMEN. El objetivo principal de este estudio es analizar los efectos del enfoque aprendizaje integrado de contenidos y lenguas extranjeras (AICLE) en la motivación de los estudiantes turcos de inglés como lengua extranjera en un programa de preparación de idiomas de una universidad privada en Estambul, Turquía. Los participantes fueron 19 estudiantes y un instructor de una clase preparatoria de nivel intermedio. En este estudio, mientras que los datos cuantitativos se recopilaron a través de cuestionarios previos y posteriores a la motivación, los datos cualitativos se recopilaron a través de diarios de reflexión de los estudiantes y del instructor. Los resultados del estudio mostraron que la implementación del enfoque AICLE influyó de manera positiva en la motivación de los estudiantes con respecto al aprendizaje del inglés. Adicionalmente, los hallazgos de los diarios de reflexión sugirieron que tanto los estudiantes como su instructor consideraron que AICLE es un enfoque eficaz, interesante y funcional para la enseñanza y el aprendizaje del inglés, ya que incluye contenido informativo y atractivo. Por otro lado, AICLE también hizo responsables a los estudiantes de su propio aprendizaje. Finalmente, ambos grupos de participantes compartieron las dificultades que tuvieron, tales como tiempos, carga de trabajo y hablar durante el uso de AICLE mediante sugerencias, particularmente en cuanto al contenido de las unidades de AICLE.

Palabras clave (Fuente: tesauro de la Unesco): aprendizaje integrado de contenidos y lenguas extranjeras; AICLE; motivación; enseñanza superior; inglés; enseñanza de idiomas; aprendizaje de idiomas; aprendizaje de lenguas.

RESUMO. O objetivo principal deste estudo é analisar os efeitos da abordagem aprendizagem integrada de conteúdos e línguas estrangeiras (AICLE) na motivação de estudantes turcos de inglês como língua estrangeira em um programa de preparação de línguas de uma universidade privada em Istambul, na Turquia. Os participantes foram 19 alunos e um instrutor de uma aula preparatória de nível intermediário. Neste estudo, enquanto os dados quantitativos foram coletados através de questionários antes e depois da motivação, os dados qualitativos foram coletados através de diários de reflexão dos alunos e do instrutor. Os resultados do estudo mostraram que a implementação da abordagem AICLE influenciou de maneira positiva a motivação dos alunos em relação à aprendizagem do inglês. Além disso, os resultados dos diários de reflexão sugeriram que tanto os alunos quanto o instrutor consideraram que AICLE é uma abordagem eficaz, interessante e funcional para ensinar e aprender inglês, já que inclui conteúdo informativo e envolvente. AICLE também responsabilizou os alunos pela sua própria aprendizagem. Finalmente, ambos os grupos de participantes partilharam as dificuldades que tiveram em termos de, por exemplo, tempos, carga de trabalho e fala durante o uso de AICLE, fazendo sugestões, particularmente no que diz respeito ao conteúdo das unidades de AICLE.

Palavras-chave (Fonte: tesauro da Unesco): motivação; ensino superior; inglês; ensino de línguas; aprendizagem de idiomas; aprendizagem de línguas. 


\section{Introduction}

In the last decade, European education systems have been attaching greater importance to second language (L2) education, as it is important to provide people with good quality education in a globalized world in which linguistic effects are gaining more and more importance (Lasagabaster, 2008). There are various approaches to meet both students' and teachers' needs in terms of learning a second language. Content and Language Integrated Learning (CLIL) is one of these approaches that succeeds to meet these needs, as it aims to create a language learning environment within various contexts. It focuses on two main aspects of language; firstly, language as a tool for learning and teaching both content and language; secondly, its adaptability and dimension of situational and contextual variables (Coyle, 2008).

Since the European Union (EU) supports the practice of CLIL in schools, there have been particular studies on the advantages of CLIL (Altınkamış, 2009; Nebioğlugil, 2015; Atlı, 2016) in Turkey, which is still trying to become a member of EU. The first implementation of CLIL in a Turkish context was in Anatolian High Schools. Unfortunately, CLIL was put aside in primary and secondary education as part of the national education system in the 1990s. However, CLIL in higher education continued at highly prestigious Turkish universities.

Nowadays, CLIL is on the rise in Turkey. Besides being implemented in higher education, many private schools from primary and secondary education have started to use this approach in various subjects. Specifically, with this approach, teachers use the target language (e.g., English) as a tool to introduce the content (Mehisto, Marsh, \& Frigols, 2008).

However, although CLIL has been adopted in various educational subjects, the number of research works particularly focusing on the effectiveness of CLIL on the students' motivation and language achievement in English classrooms is scarce (Altınkamıs, 2009). The present study, therefore, intends to fill this gap by integrating CLIL in intermediate level English classrooms and to investigate its effects on students' motivation while studying at the language school of a private university in Turkey. The study also attempts to find out how 
students and their instructors perceive learning and teaching English with this particular approach. By implementing this approach, the study aims to provide students with the opportunities to improve their English through various interesting and appealing subjects that will also increase their motivation.

After the 2000s, there was an increase in the implementation of CLIL programs, which were observed to differ in terms of intensity of language and content integration. The most common languages used in CLIL programs in Europe are English, French, and German. Between 2006 and 2009, the ProCLIL project was created, which was financed by the EU and involved four countries, namely Germany, Spain, England, and Turkey. The purpose of the project was to explore how primary school teachers, learners, and parents perceived CLIL in the beginning and at the end of the implementation process. The experiences and attitudes of the participants were described and interpreted comprehensively. The findings indicated that primary school teachers focused more on the content while teaching English. The teachers, students and their parents also perceived CLIL as a positive instructional tool to help students with their language development.

Furthermore, a study carried out by Sylvén (2004) showed that the amount of exposure to English outside of school was more important for the students to learn vocabulary than implementing CLIL in schools. The study investigated the incidental vocabulary acquisition of 99 CLIL learners by comparing a control group of 264 "traditional" students who were exposed to vocabulary tests three times during two full school years. In addition to the vocabulary tests, 363 students filled out questionnaires concerning personal background. The results reported that the CLIL students outperformed the control group in the tests, and their attitudes towards learning vocabulary being exposed to CLIL were positive. Similar to this study, Arribas (2016) attempted to discover the outcomes of the students' receptive vocabulary aside from their motivation towards learning English. The results showed 
that the CLIL group scored higher in receptive vocabulary tests due to their higher motivation.

In another study, Pistorio (2010) introduced an approach in which cooperative learning in a CLIL context was used to enable a socially constructed learning environment. Unlike traditional approaches, CLIL was selected as a pedagogical tool to integrate language and content instruction in an English classroom. According to the results, there was an increase in the overall language achievement of the students. Being exposed to CLIL also helped students become more autonomous, self-directed and intrinsically motivated learners. Lasagabaster (2011) conducted a parallel study on student motivation in two different settings, a CLIL classroom and a non-CLIL or English as a Foreign Language (EFL) classroom. Specifically, this research aimed to examine the relationship between motivation and language proficiency of 191 secondary school students. The findings revealed that CLIL had a more effective and significant impact on the students' motivation and their language proficiency. In a more recent study, Lasagabaster and Beloqui (2015) conducted a study on the implementation of CLIL and non-CLIL approaches and the two types of methodology based on either the textbook or project work (PW). In particular, this research focused on primary education students. The results obtained from the questionnaires showed that CLIL was beneficial for some motivational clusters even at an early age, whereas the impact of PW was not as positive as expected.

Navarro-Pablo and Jiménez (2018) conducted another recent study investigating whether CLIL students are more motivated than nonCLIL students while learning English. The study also investigated the students' overall language attainment (use of English, vocabulary, listening, speaking, and reading). The participants were 352 primary and secondary school students. The findings showed slightly different results. In primary schools, for instance, the CLIL students outperformed non-CLIL students in all the subtests. However, the differences were not statistically significant for all of them. CLIL seemed to have less effect on receptive skills compared to productive skills. The study also confirmed prior findings about the interaction of motivation and language attainment that revealed higher levels of motivation to CLIL strands.

Apart from CLIL studies in primary and secondary education, Savignon and Wang (2003) and Verma (2008) aimed to find out the students' 
motivation and their attitudes towards CLIL at university level. The findings revealed that the university students were more motivated and they had positive attitudes about learning English with this particular approach. In addition, Montoya and Salamanca (2017) designed content-based activities and gave university teachers training about how they can use these activities in their English classrooms. The results reported that the teachers were positive and they expressed that they got familiar with the pedagogical advantages of the CLIL approach. Another CLIL study was carried out by Dalton-Puffer (2009), who examined the students' perceptions towards learning English through the CLIL approach. The results of the questionnaires and in-depth interviews revealed that CLIL encouraged learners to talk and to think by themselves. The students felt more motivated and they focused more on communication rather than grammatical correctness. The study concluded that there is a positive relationship between the students' perceptions towards CLIL and the theoretical features of this particular approach.

In brief, the previous studies on CLIL show the effectiveness of using this particular approach as an instructional tool in English language classrooms. The present study, therefore, aims to investigate the influence of CLIL on the students' motivation in English classrooms and find out how this approach is perceived by students and their instructor at a language preparatory school of a private university in Turkey. The following research questions were addressed in this research:

1. To what extent does incorporating CLIL have impact on the students' motivation in an English language preparatory school?

2. What are the perceptions of the students and their instructor about learning English through CLIL-based lessons?

\section{Method}

\section{Research design}

For the purposes of this study, an action research was used to investigate and to understand the process that occurs as part of an educational change to lead to better teaching practices (Burns \& Hood, 
1995; Borg, 2002). Specifically, in this action research, the instructors as the exploratory researchers (Smith \& Robolledo, 2018) attempted to get in-depth information about the process of implementing CLIL at an intermediate level English classroom offered by a language preparatory school of a private university in Turkey. Specifically, the aim was to find out the effects of CLIL on students' motivation and to reveal the perceptions of students and their instructor about CLIL-based lessons.

\section{Context}

The present study was conducted at an English language preparatory school, which was a private university located in Istanbul, Turkey. Students enrolled in this program are required to complete the program with an upper-intermediate (B2) English level. In the this program, there are four modules (A2, B1, B1+, and B2) identified by the Common European Framework of Reference for Languages (CEFRL) that the students have to complete successfully before they start their respective undergraduate programs. Each module lasts for a total of 8 weeks. Every week students have 24 hours of English lessons, which include the four language skills of reading, listening, writing, and speaking, plus the main course lesson, which mainly focuses on teaching grammar and vocabulary.

\section{Participants}

The participants of this action research were 19 Turkish students (9 females and 10 males) learning English in the preparatory school and their instructor, who was one of the exploratory researchers in this study. The students were at intermediate (B1) level and their age range was between 18 and 23 years old. The students were expected to complete this preparatory program with a B2 level to start their undergraduate programs at various disciplines. Table 1 shows the demographic information of the students: 
Table 1. Demographic information of the students

\begin{tabular}{|c|c|c|}
\hline Age & Frequency & (\%) \\
\hline $18-20$ & 17 & 89.5 \\
\hline $20+$ & 2 & 10.5 \\
\hline Total & 19 & 100.0 \\
\hline Gender & Frequency & $\mathbf{( \% )}$ \\
\hline Female & 9 & 47.4 \\
\hline Male & 10 & 52.6 \\
\hline Total & 19 & 100.0 \\
\hline High school & Frequency & Percentage (\%) \\
\hline Private & 4 & 21.1 \\
\hline State & 15 & 78.9 \\
\hline Total & 19 & 100.0 \\
\hline Abroad & Frequency & Percentage (\%) \\
\hline Yes & 4 & 21.1 \\
\hline No & 15 & 78.9 \\
\hline Total & 19 & 100.0 \\
\hline
\end{tabular}

Source: Own elaboration.

Furthermore, the instructor who participated in this study was offering the main course for a total of 12 hours per week. She was a 24-year-old female with 5 years of teaching experience who has been working at the English preparatory school for three years.

\section{Instruments of Data Collection}

In this study, the data was collected using both quantitative and qualitative methods. Specifically, the motivation questionnaire was used to get quantitative data while the reflective journals were used to get qualitative data.

Motivation questionnaire. In order to see the effects of CLIL-based lessons on the students' motivation, a close-ended motivation questionnaire was adapted from the study of Schmidt, Boraje, and Kassabgy (1996). In line with the research question, which is investigating the effectiveness of CLIL-based lessons on students' motivation, only the 
motivation part, which consisted of 50 items was administered in the study. The questionnaire was written in English and verbally translated into Turkish by the course instructor. Two of the original items in the questionnaire were adapted according to the present study's context. Since the participants of the present study were Turkish, the term Egypt in the original questionnaire was changed to Turkey in item 9. Another adaptation was made in item 48 , which states "After I finish this class, I will probably take another English course." Specifically, it was changed to "After I finish this module, I would like to get the same course in a similar way." It was found that it was necessary to change this item because the aim of this study was to familiarize the students with the CLIL approach. Therefore, the students do not have a chance to select another CLIL course in the preparatory program. They can only state their perceptions that they would like to get more CLIL-based courses.

Reflective journals. The qualitative instruments used to collect the necessary data involved the students' and the instructor's reflective journals that they kept each week right after the CLIL-based lessons. Learners reflected their perceptions on the on-going learning and teaching activities by keeping a reflective journal. Students were asked to write on the journals specifically after each CLIL unit in order to collect in-depth information about the perceptions of the participants. The students wrote their thoughts and experiences related to the CLIL units, whereas the instructor took field notes on the students' attitudes towards the units.

\section{Data analysis}

To analyse the quantitative data obtained from the motivation questionnaire, an independent sample t-test was used to compare the motivation level of the students before and after implementing CLIL. In addition, the qualitative data gathered from the reflective journals were analysed by means of inductive analysis as the themes from the raw data emerged through repeated reading and comparison (Creswell, 2007). The researcher firstly analysed the written data through open coding approach. Then, she grouped the data reducing the number of categories by combining the similar themes into broader categories. The researcher also conducted the data analysis procedure and had the themes reviewed by a colleague who was an expert in the field. 


\section{Data Collection Procedures}

During the first week of the implementation, the motivation questionnaire was given out to the students to investigate the effect of CLIL lessons on their motivation. After collecting the data from the pre-motivation questionnaire, the researcher presented the CLIL units, which were integrated into the existing syllabus. As the researcher did not find the current course book to be sufficient, she met with the course coordinators and they agreed on the idea that giving linguistic instructions implicitly within various contents would be more effective for adult learners than explicit instruction. Therefore, they came up with eight CLIL units that were meant to be covered over the course of eight weeks. In accordance with the aim of this study, the researcher and her colleagues designed an outline of the CLIL-based lessons in line with all the 4Cs of CLIL introduced by Coyle (2008). During the implementation of CLIL, different contents such as social studies, art, history, science and geography were included as the major content in the lesson plans. The researcher, who was also the instructor of this English classroom, prepared a lesson plan for each CLIL unit and introduced the target structure and words in line with the themes suggested in the lesson plans. The CLIL units were incorporated for a total of eight weeks, during which the researcher collected the relevant qualitative and quantitative data. Table 2 shows the chronological order of the data collection process.

Table 2. Chronological order of the CLIL-units and Data Collection Procedure

\begin{tabular}{|l|c|}
\hline \multicolumn{1}{|c|}{ CLIL-Units and Data Collection Tools } & Date \\
\hline Permission approval by the Head of the English Language School & November \\
Pre-motivation Questionnaire & $14-15,2017$ \\
WEEK 1 & \\
CLIL-Unit 1: Being Bilingual & \\
Reflective Journals & November \\
\hline WEEK 2 & $21-22,2017$ \\
CLIL-Unit 2: How was Earth Formed? & \\
Reflective Journals & November \\
\hline WEEK 3 & $28-29,2017$ \\
CLIL-Unit 3: Nagykanizsa Castle & \\
Reflective Journals & \\
\hline
\end{tabular}




\begin{tabular}{|l|c|}
\hline \multicolumn{1}{|c|}{ CLIL-Units and Data Collection Tools } & Date \\
\hline WEEK 4 & December \\
CLIL-Unit 4:The Changing of Anasazi and New York & $05-06,2017$ \\
Reflective Journals & \\
\hline WEEK 5 & December \\
CLIL-Unit 5: The Future of the Universe & $12-13,2017$ \\
Reflective Journals & \\
\hline WEEK 6 & December \\
CLIL-Unit 6: How to Help Homeless People & $19-20,2017$ \\
Reflective Journals & \\
\hline WEEK 7 & December \\
CLIL-Unit 7: Two British Philosophers & $26-27,2017$ \\
Reflective Journals & \\
\hline WEEK 8 & January \\
CLIL-Unit 8: What if? & $02-04,2017$ \\
Reflective Journals & \\
Post-motivation Questionnaire & \\
\hline
\end{tabular}

Source: Own elaboration.

\section{Results}

\section{The impact of CLIL-based lessons}

The results regarding student motivation were found through a preand post-motivation questionnaire by means of quantitative methods. In addition to the motivation questionnaire, the perceptions of the participants regarding the CLIL approach were investigated through weekly reflective journals by means of a qualitative method. The respective findings are presented next.

\section{The impact of CLIL-based lessons on student motivation}

The extent of the students' motivation was investigated via the preand post-motivation questionnaire in order to explore the effects after the implementation. Table 3 reveals the normality test results regarding the students' motivation.

According to the results of the normality tests, the pre- and posttest scores were normally distributed ( $p>0.05)$.

In addition, a paired sample t-test was conducted to determine whether there was a difference in the students' motivation level after the pre- and post-tests (Table 4). 
Table 3. Normality test results

\begin{tabular}{|c|c|c|c|c|c|c|}
\hline & \multicolumn{3}{|c|}{ Kolmogorov-Smirnova } & \multicolumn{3}{c|}{ Shapiro-Wilk } \\
\cline { 2 - 7 } & Statistic & DF & SIG. & Statistic & DF & SIG. \\
\hline Pre-test & .164 & 19 & .195 & .953 & 19 & .439 \\
\hline Post-test & .149 & 19 & $.200^{\star}$ & .942 & 19 & .292 \\
\hline
\end{tabular}

Source: Own elaboration.

Table 4. Differences between Pre- and Post-motivation questionnaire

\begin{tabular}{|c|c|c|c|c|c|c|}
\hline \multirow{2}{*}{ Education } & Test & $\mathrm{N}$ & & $\mathrm{SD}$ & $\mathrm{t}$ & $\mathrm{p}$ \\
\hline \multirow{2}{*}{ Motivation } & Pre-test & 19 & 2.44 & 010 & & \\
\cline { 2 - 7 } & Post-test & 19 & 3.05 & 0.18 & -18.107 & 0.000 \\
\hline
\end{tabular}

Source: Own elaboration.

According to the results of the paired sample t-test, the level of motivation compared to the test group was found to be statistically significant at a 95\% confidence level ( $t=-18.107, p=0.000, p<0.05)$. Specifically, the motivation level of the final test group $\left(x^{-}=3.05\right)$ was found to be higher than that of the pre-test group $\left(x^{-}=2.44\right)$.

\section{Perceptions of the students and the instructor regarding CLIL-based lessons}

After completing the inductive analysis through an open-coding approach, the researcher identified six major themes from the reflective journals, namely, effective way for vocabulary retrieval, functional for the use of English language, engaging process of learning, raising a feeling of responsibility, difficulties encountered, and, finally, suggestions to improve the units. The following paragraph explains each theme, presenting the in-depth explanations followed by the excerpts of the participating students and their instructor.

Effective way for vocabulary retrieval. In the reflective journals, both students and their instructor reflected that learning English through CLIL-based units helped them to retrieve the target vocabulary more easily as they constantly appeared within different parts of the unit. 
The students practiced these words and they also made sentences within the given context. The following excerpts support this finding:

Our vocabulary knowledge develops and we can focus easily in the lesson. We use the same words and make relevant sentences in the activities again and again. (S14, Journal Data, 22.11.2017)

In the lesson, I learned many new words. Learning different topics improves our vocabulary knowledge and we easily use the words we learned. (S19, Journal Data, 22.11.2017)

Similarly, the instructor noted in the journals that there was a considerable increase in the students' vocabulary development, as the students were asked to actively use the target words and make meaningful sentences. Considering this finding, the instructor said:

In the CLIL-units, students learn through different topics. This way, they became familiar with the content and target vocabulary. Afterwards, they use these words and make meaningful sentences. (T, Journal Data, 29.11.2017)

Furthermore, the students found some vocabulary activities to be challenging yet useful, stating that they had some difficulties understanding the text, as shown in this excerpt:

Vocabulary activities were a little bit challenging. The texts were sometimes difficult to understand. But I learned many useful words. (S13, Journal Data, 04.01.2018)

In brief, the reflections of the students and their instructor showed that the CLIL approach improved the students' vocabulary and also developed their ability to use the target words in a meaningful way.

Functional for the use of English language. According to the reflections of students, the CLIL units helped them to use the linguistic structures accurately and also developed their grammar performance as well. Through CLIL units, the students were constantly required to make sentences both while speaking and writing about the target content, as displayed below:

I can make correct sentences while speaking and writing about the given topic. (S19, Journal Data, 13.12.2017)

In addition, one of the students compared the previous English lesson with the CLIL lesson. The student stated that he can use the 
target words freely and make more meaningful sentences rather than just memorize the rules. The following excerpt supports this finding:

In the lesson, I can use the words freely and make meaningful sentences after reading the text. Before, we only memorized the rules and it was unnecessary. (S10, Journal Data, 20.12.2017)

Some of the participants also associated the CLIL content with the subjects they will learn when they start their undergraduate program. Parallel to this finding, one of the students said:

I liked the philosophical words the most, because I will be studying sociology and I know that we will learn these in my undergraduate program. (S4, Journal Data, 27.12.2017)

Furthermore, the instructor also noted in the journals that CLILbased lessons also helped students to improve their grammar performance. To exemplify, the students were able to make proper use of the target structures during activities both in and outside of class, as displayed in the following comment:

When I gave them the example sentences on present simple and present continuous after reading the CLIL text and watching the videos, the students made more accurate sentences. They also made similar sentences in their assignments outside the class. (T, Journal Data, 15.11.2017)

To summarize, the findings of the reflective journals indicated that, after being introduced to the content including the target structure and vocabulary, the students used the target words and structures meaningfully and accurately.

Engaging process of learning. The findings of the reflective journals revealed that the participating students found the contents in the CLIL units to be very informative and engaging. They could learn new information from real life, which is displayed in these excerpts:

I am normally not interested in this kind of things. But I find this "Earth" text useful. I learned new information from real life and it was really useful. (S12, Journal Data, 22.11.2017)

It was a very inspiring "Ottoman" text. I didn't learn it in high school, or on books before. I liked reading it in English and it was so real. (S18, Journal Data, 29.11.2017) 
Similarly, the instructor reflected that students seemed more engaged during the CLIL lessons and that they were interested in the content, as shown below:

Students didn't even want to have break times when we were discussing the issue of how the Earth will end. One of them stated that this topic is something that he always wondered about and he really enjoyed the topic. (T, Journal Data, 13.12.2017)

To summarize, both students and the instructor perceived CLIL as a motivating and engaging instructional approach in English classrooms. Being exposed to this approach helped students improve their English effectively.

Raising a feeling of responsibility. The findings gathered from the instructor's reflective journals indicated that students were willing to complete their tasks both inside and outside of class. This helped the students take responsibility for their own learning, as expressed in this comment:

When students heard that they were going to choose a landmark and make a presentation about it, they suddenly started to think about a landmark, searched the topic outside the class and came up with several ideas. (T, Journal Data, 29.11.2017)

To wrap up, the findings of the reflective journals demonstrated that the students were willing to complete the tasks related to the CLIL units and that they enjoyed this process. Learning and practicing English with CLIL increased their responsibility for learning.

Difficulties encountered. During the CLIL-based lessons, the students were expected to complete a task each week. Some of the students claimed that they needed more time to complete the task due to their heavy work load. Similarly, the instructor reflected that students had many language tasks to complete in the preparatory school and, therefore, experienced some timing problems. Considering this finding, the participants said:

I had difficulty when preparing the presentation on how to help homeless people because I didn't have enough time. I had a grammar quiz on the same day. (S3, Journal Data, 20.12.2017)

The students' have many assignments to complete in the preparatory school. Some of the students stated that two days weren't enough 
to complete their presentation assignment, which shows their workload. (T, Journal Data, 27.12.2017)

Moreover, some of the students reflected on the difficulty they faced with the speaking parts of the CLIL-based lessons. They noted that they felt that they did not know enough to talk about the tasks or they felt shy, as displayed in this excerpt:

I didn't use to fully understand what is said in English before. But now, I can understand more easily. However, I still have difficulty in speaking about the topics and sometimes I feel shy. (S16, Journal Data, 06.12.2017)

Similar to the students' reflections, the instructor noted that some students either wanted to speak in Turkish or did not want to participate during oral activities, as shown below:

Some of the students asked if they could speak in Turkish when sharing their ideas about the topic. Others were not willing to speak at all. (T, Journal Data, 29.11.2017)

To wrap up, despite the fact that most of the students seemed to improve their grammar performance and vocabulary knowledge, some students experienced difficulty in speaking tasks. They did not know enough about the subject and they felt shy to speak in English. Finally, the students also had some timing problems while completing the assignments due to their heavy schedules in the preparatory school.

Suggestions to improve the units. According to their reflections about improving the existing CLIL units, students suggested that every single topic could be accompanied by a video to support the listening track. They also suggested that content related to their own country could be included in more detail. The following excerpts support these findings:

We could have watched a video of those places in London. Watching videos and listening to tracks would be more informative and fun. (S17, Journal Data, 29.11.2017)

We could have learned more about how cities in our country have changed within time. (S3, Journal Data, 06.12.2017)

In addition to the visual and audio presentation of the CLIL units, the students shared some units they would like to learn more about as shown below: 
Greek, Indian or Italian philosophers could have been added. This would be fun. (S2, Journal Data, 27.12.2017)

More traditions of British people would be interesting to learn in the lesson. (S11, Journal Data, 29.11.2017)

Overall, the reflections of students and their instructor revealed that both groups of participants perceived CLIL-based lessons as interesting and informative. This particular approach helped students to particularly improve their grammar performance and vocabulary knowledge. The students were also more engaged in the lesson and they became more responsible for their own learning. Apart from a couple of difficulties that the students experienced, such as timing and speaking problems, as well as a heavy workload, CLIL-based units increased their motivation and interest in the lesson.

\section{Discussion}

As presented in the previous part of this study, the findings obtained from the motivation questionnaire revealed that students felt more motivated and engaged after being exposed to CLIL units. This finding is in accordance with previous studies (Altınkamıs, 2009; Lasagabaster \& Sierra, 2009; Savignon \& Wang, 2003; Verma, 2008; Montoya \& Salamanca, 2017).

Moreover, as highlighted in this study, as well as in similar studies (Lasagabaster, 2011; Lasagabaster \& Beloqui, 2015; Navarro-Pablo \& Jiménez, 2018; Pistorio, 2010), the students started to take more responsibility for their own learning, not just in but also outside the class after CLIL-based lessons. Besides the sense of responsibility, they improved their grammar performance, as well as their vocabulary knowledge in English. These findings clearly show the positive impact of CLIL on the students' language achievement.

Furthermore, the results gathered from the reflective journals showed that the majority of students and their instructor shared positive perceptions about CLIL-based lessons as a way to be actively engaged in English lessons. Specifically, the students were willing to per- 
form the CLIL tasks and they were motivated to learn English through interesting and informative content. Likewise, the students perceived CLIL as a functional instructional tool to prepare them for their undergraduate programs.

To conclude, CLIL-based lessons were found to be engaging and informative during teaching, learning and practicing English in the preparatory course. This finding supports that using CLIL in English classes leads to more practical, natural and interactive educational context.

\section{Recommendations}

The present study offers some recommendations for further research studies. First of all, this study included a small number of students. Therefore, replicating the study using a larger sample size could lead to more generalizable results.

Furthermore, the study was conducted over a total of eight weeks. The incorporation of CLIL for a longer period could lead to more detailed results in relation to the impact of CLIL on the students' vocabulary development.

Finally, as this study was an action research, it included only one sample group. For further studies, adding a control group could reveal more comparative results. Therefore, the results of this study should be taken as suggestive for further CLIL studies.

\section{References}

Altınkamış, T. (2009). A case study on the relation between content and language integrated learning (CLIL) and motivation in language learning (Unpublished master's thesis). Cukurova University, Institute of Social Sciences, Adana, Turkey.

Arribas, M. (2016). Analysing a whole CLIL school: Students' attitudes, motivation, and receptive vocabulary outcomes. Latin American Journal of Content and Language Integrated Learning, 9(2), 267-292. DOI: 10.5294/ lacli1.2016.9.2.2 
Borg, S. (2002). Research in the lives of TESOL professionals. TESOL Matters, 13(1), 1-5. DOI: 10.1016/j.tate.2006.03.012

Burns, A., \& Hood, S. (1995). Teachers' voices: Exploring course design in a changing curriculum. Sydney, Australia: National Centre for English Language Teaching and Research. Retrieved from https://eric.ed.gov ? $\mathrm{id}=\mathrm{ED} 411711$

Coyle, D. (2008). CLIL: A Pedagogical Approach from the European Perspective. In N. H. Hornberger (Ed.), Encyclopedia of Language and Education (pp. 97-112). Berlin, Germany: Springer-Verlag Berlın. DOI: 10.1007/978-0-387-30424-3

Creswell, J. W. (2007). Qualitative inquiry and research design: Choosing among five approaches (2nd Ed.). Thousand Oaks, CA: Sage Publications, Inc. Retrieved from http://www.ceil-conicet.gov.ar/wp-content/uploads/2018/04/CRESWELLQualitative-Inquary-and-Research-Design-Creswell.pdf

Dalton-Puffer, C. (2009). Communicative competence and the CLIL lesson. In Y. Ruiz de Zarobe \& R. M. Jiménez-Catalán (Eds.), Content and language integrated learning. Evidence from research in Europe (pp. 197-214). Bristol, UK: Multilingual Matters. Retrieved from https://www. researchgate.net/publication/292424290_Communicative_competence_and_the_CLIL_lesson

Lasagabaster, D. (2008). Foreign language competence in content and language integrated courses. The Open Applied Linguistics Journal, 1, 31-42. Retrieved from https://www.unifg.it/sites/default/files/allegatiparagrafo/20-01-2014/lasagabaster_foreign_language_competence_and_language_integrated_courses.pdf

Lasagabaster, D., \& Sierra, J. M. (2009). Immersion and CLIL in English: More differences than similarities. ELT Journal, 64(4), 367-375. DOI: 10.1093/elt/ccp082

Lasagabaster, D. (2011). English achievement and student motivation in CLIL and EFL settings. Innovation in Language Learning and Teaching, 5(1), 3-18. DOI: 10.1080/17501229.2010.519030

Lasagabaster, D, \& Lopez-Beloqui, R. (2015). The impact of type of approach (CLIL versus EFL) and methodology (book-based versus project work) on motivation. Porta Linguarum, 23, 41-57. Retrieved from https://www.researchgate.net/publication/279331816_The_Impact_ of_Type_of_Approach_CLIL_Versus_EFL_and_Methodology_BookBased_Versus_Project_Work_on_Motivation 
Lo, Y. Y., \& Lin, A. M. (2015). Special issue: Designing multilingual and multimodal CLIL frameworks for EFL students. International Journal of Bilingual Education and Bilingualism, 18(3), 261-269. Retrieved from https:// www.researchgate.net/profile/Angel_Lin/publication/276915308_ Special_issue_Designing_multilingual_and_multimodal_CLIL_ frameworks_for_EFL_students/links/562e1cf608aef25a2443a06a/ Special-issue-Designing-multilingual-and-multimodal-CLIL-frameworks-for-EFL-students.pdf

Lo, Y. Y., \& Macaro, E. (2012). The medium of instruction and classroom interaction: Evidence from Hong Kong secondary schools. International Journal of Bilingual Education and Bilingualism, 15(1), 29-52. DOI: 10.1080/13670050.2011.588307

Lo, Y. Y., \& Macaro, E. (2015). Getting used to content and language integrated learning: What can classroom interaction reveal? The Language Learning Journal, 43(3), 239-255, DOI: 10.1080/09571736.2015.1053281

Montoya, S. I., \& Salamanca, C. (2017). Uso del enfoque aicle/clil como estrategia de internacionalización del currículo en una institución de educación superior colombiana. Latin American Journal of Content and Language Integrated Learning, 10(1), 105-131. DOI: 10.5294/lacli1.2017.10.1.5

Navarro-Pablo, M., \& Jiménez, E. G. (2018). Are CLIL students more motivated? An analysis of affective factors and their relation to language attainment. Porta Linguarum, 29, 71-90. Retrieved from https://www. researchgate.net/publication/322506930_Are_CLIL_Students_More_ Motivated_An_Analysis_of_Affective_Factors_and_their_Relation_ to_Language_Attainment_Porta_Linguarum

Nebioğlugil, M. (2015). A case study on the implementation of content and language integrated learning in teaching vocabulary to young learners (Master's thesis). Cag University, Institute of Social Sciences, Adana, Turkey.

Nikula, T. (2010). Effects of CLIL on a teacher's classroom language use. In C. Dalton-Puffer, T. Nikula, \& U. Smit (Eds.), Language use and language learning in CLIL classrooms (pp. 105-123). Amsterdam, The Netherlands: John Benjamins. DOI: 10.1075/aals.7

Pistorio, M. I. (2010). A blend of CLIL and cooperative learning creates a socially constructed learning environment. Latin American Journal of Content \& Language Integrated Learning, 3(1), 1-10. Retrieved from: http://laclil.unisabana.edu.co/index.php/LACLIL/article/view/2642 
Savignon, S., \& Wang, C. (2003). Communicative language teaching in EFL contexts: Learners' attitudes and perceptions. International Review of Applied Linguistics in Language Teaching, 41, 223-249. DOI: 10.1515/ iral.2003.010

Schmidt, R., Boraie, D., \& Kassabgy, O. (1996). Foreign language motivation: Internal structure and external connections. University of $\mathrm{Ha}$ wai'i Working Papers in English as a Second Language, 14(2), 1-72. Retrieved from http://nflrc.hawaii.edu/PDFs/SCHMIDT\%20Foreign\%20 language\%20motivation.pdf

Smith, R., \& Rebolledo, P. (2018). A handbook for exploratory action research. London, UK: The British Council. Retrieved from https://englishagenda.britishcouncil.org/sites/default/files/attachments/30510_bc_ explore_actions_handbook_online_aw.pdf

Sylvén, L. K. (2004). Teaching in English or English Teaching? On the effects of content and language integrated learning on Swedish learners' incidental vocabulary acquisition (Unpublished doctoral dissertation). Gothenburg, Sweden: Göteborgs University.

Verma, M. H. (2008, June). Learner's attitude and its impact on language learning. Paper presented at Language Issues in English-medium Universities: A Global Concern, Rayson Huang Theatre, University of Hong Kong, China, 18-20 June 2008. Retrieved from http://www.fe.hku. hk/clear/conference08/doc/handouts/VERMA\%20Meenakshi\%20H_ handout.pdf 